\title{
Early Pharmacotherapy Restores Neurogenesis and Cognitive Performance in the Ts65Dn Mouse Model for Down Syndrome
}

\author{
Patrizia Bianchi, ${ }^{1}$ Elisabetta Ciani, ${ }^{1}$ Sandra Guidi, ${ }^{1}$ Stefania Trazzi, ${ }^{1}$ Daniela Felice, ${ }^{1}$ Gabriele Grossi, ${ }^{2}$ \\ Mercedes Fernandez, ${ }^{3}$ Alessandro Giuliani, ${ }^{3}$ Laura Calzà, ${ }^{3}$ and Renata Bartesaghi ${ }^{1}$ \\ ${ }^{1}$ Department of Human and General Physiology, University of Bologna, I-40126 Bologna, Italy, ${ }^{2}$ Center for Applied Biomedical Research, S. Orsola-Malpighi \\ University Hospital, I-40138 Bologna, Italy, and ${ }^{3}$ BioPharmaNet-Department of Veterinary Morphophysiology and Animal Production, University of \\ Bologna, I-40064 Bologna, Italy
}

\begin{abstract}
Down syndrome (DS) is a genetic pathology characterized by intellectual disability and brain hypotrophy. Widespread neurogenesis impairment characterizes the fetal and neonatal DS brain, strongly suggesting that this defect may be a major determinant of mental retardation. Our goal was to establish, in a mouse model for DS, whether early pharmacotherapy improves neurogenesis and cognitive behavior. Neonate Ts65Dn mice were treated from postnatal day (P) 3 to P15 with fluoxetine, an antidepressant that inhibits serotonin (5-HT) reuptake and increases proliferation in the adult Ts65Dn mouse (Clark et al., 2006). On P15, they received a BrdU injection and were killed after either $2 \mathrm{~h}$ or 1 month. Results showed that P15 Ts65Dn mice had notably defective proliferation in the hippocampal dentate gyrus, subventricular zone, striatum, and neocortex and that proliferation was completely rescued by fluoxetine. In the hippocampus of untreated P15 Ts65Dn mice, we found normal 5-HT levels but a lower expression of 5-HT1A receptors and brain-derived neurotrophic factor (BDNF). In Ts65Dn mice, fluoxetine treatment restored the expression of 5-HT1A receptors and BDNF. One month after cessation of treatment, there were more surviving cells in the dentate gyrus of Ts65Dn mice, more cells with a neuronal phenotype, more proliferating precursors, and more granule cells. These animals were tested for contextual fear conditioning, a hippocampusdependent memory task, and exhibited a complete recovery of memory performance. Results show that early pharmacotherapy with a drug usable by humans can correct neurogenesis and behavioral impairment in a model for DS.
\end{abstract}

\section{Introduction}

Down syndrome (DS) is a high-incidence disease ( 1 of 700-1000 live births) caused by trisomy of chromosome 21 . DS produces a variable set of clinical features but mental retardation remains the invariable hallmark and the most invalidating aspect of this pathology, with a hard impact on public health.

Mental retardation has been related to the decreased brain size of DS individuals. Brain hypoplasia and hypocellularity are present in children and even fetuses with DS (Rachidi and Lopes, 2008), suggesting that defective neuronogenesis during early developmental stages may be a major determinant of microencephaly and, hence, of intellectual disability. Consistent with this idea, various laboratories have shown severe proliferation defects in the developing neocortex, dentate gyrus, and cerebellum of mouse models for DS (Haydar et al., 2000; Lorenzi and Reeves, 2006; Roper et al., 2006b; Chakrabarti et al., 2007; Contestabile et al., 2007) and in the hip-

Received Jan. 30, 2010; revised April 16, 2010; accepted May 11, 2010.

This work was supported by a grant from the Fondation Jerome Lejeune to R.B.

Correspondence should be addressed to Prof. Renata Bartesaghi, Dipartimento di Fisiologia Umana e Generale,

Piazza di Porta San Donato 2, I-40126 Bologna, Italy. E-mail: renata.bartesaghi@unibo.it.

DOI:10.1523/JNEUROSCI.0534-10.2010

Copyright $\odot 2010$ the authors $\quad 0270-6474 / 10 / 308769-11 \$ 15.00 / 0$ pocampal region of DS fetuses (Contestabile et al., 2007; Guidi et al., 2008).

The serotonergic, noradrenergic, GABAergic, and cholinergic systems are altered in trisomic mice and DS fetuses (Bar-Peled et al., 1991; Fiedler et al., 1994; Dierssen et al., 1997; Granholm et al., 2000; Kleschevnikov et al., 2004; Whittle et al., 2007) and although these alterations might be involved in neurogenesis impairment, the mechanisms underlying this defect are far from being elucidated. Consequently, no rational basis exists on which to devise therapeutic strategies aimed at improving neurogenesis in DS. Accumulating evidence shows that antidepressants increase neurogenesis in the dentate gyrus and subventricular zone of the lateral ventricle (Malberg et al., 2000; Shankaran et al., 2006). This raises the exciting possibility of pharmacologically improving neurogenesis with drugs that are usable by humans to correct brain pathologies characterized by reduced neuron production/neurodegeneration. Confirming this idea, treatment with fluoxetine, an antidepressant that inhibits serotonin (5-HT) reuptake, has been shown to increase neurogenesis in the adult Ts65Dn mouse (Clark et al., 2006). DS has long been associated with defects in the serotonergic system (Whitaker-Azmitia, 2001). In particular, the serotonin 5-HT1A receptor peaks earlier in developing DS brains and decreases to below normal levels by birth (Bar-Peled et al., 1991) and reduced 5-HT levels are present in adults with DS (Risser et al., 1997). Since 5-HT depletion 
causes a permanent reduction in neuron number in the adult brain (Whitaker-Azmitia, 2001), it is conceivable that alterations in the serotonergic systems during early life stages may contribute to the reduced neurogenesis of the DS brain.

So far, no study has explored the possibility of pharmacologically improving neurogenesis defects in DS during critical periods of brain development. Based on the above-mentioned evidence, the goals of our study were to establish whether it is possible to pharmacologically correct neurogenesis defects in DS by early treatment with fluoxetine and whether this effect leads to a behavioral improvement. To achieve these goals, we used the Ts65Dn mouse model for DS, because the genetic substrate, biological and behavioral abnormalities, and neurogenesis defects observed in this animal largely overlap with those of the human DS brain.

\section{Materials and Methods \\ Colony}

Female Ts65Dn mice carrying a partial trisomy of chromosome 16 (Reeves et al., 1995) were obtained from Jackson Laboratories and maintained on the original genetic background by mating them with C57BL/ $6 \mathrm{JEi} \times \mathrm{C} 3 \mathrm{SnHeSnJ}(\mathrm{B} 6 \mathrm{EiC} 3) \mathrm{F} 1$ males. Animals were karyotyped using real-time quantitative PCR ( $\mathrm{qPCR}$ ) as previously described (Liu et al., 2003). Genotyping was validated with fluorescent in situ hybridization (Strovel et al., 1999). The day of birth was designed as postnatal day (P) 0 . A total of 116 mice were used. The animals' health and comfort were controlled by the veterinary service. The animals had access to water and food ad libitum and lived in a room with a 12:12 h dark/light cycle. Experiments were performed in accordance with the Italian and European Community law for the use of experimental animals and were approved by Bologna University Bioethical Committee. In this study, all efforts were made to minimize animal suffering and to keep the number of animals used to a minimum.

\section{Experimental protocol}

Euploid $(n=30)$ and Ts65Dn $(n=25)$ mice received a daily subcutaneous injection (at 9-10 A.M.) of fluoxetine (Sigma-Aldrich) in $0.9 \% \mathrm{NaCl}$ solution from P3 to P15 (dose: $5 \mathrm{mg} / \mathrm{kg}$ from P3 to P7; $10 \mathrm{mg} / \mathrm{kg}$ from P8 to P15). Age-matched euploid $(n=30)$ and Ts65Dn $(n=25)$ mice were injected with the vehicle. Each treatment group had approximately the same composition of males and females. On P15, some animals received an intraperitoneal injection ( $150 \mu \mathrm{g} / \mathrm{g}$ body weight) of BrdU (5-bromo-2-deoxyuridine; Sigma-Aldrich ), a marker of proliferating cells (Nowakowski et al., 1989), in $0.9 \% \mathrm{NaCl}$ solution (at 11-12 A.M.) and were killed either after $2 \mathrm{~h}$ (on P15; 4-6 animals for each group) to examine cell proliferation, or after 1 month (on P45; 4-6 animals for each group) to examine the fate of the BrdU-labeled cells. Before death, in the period from P43 to $\mathrm{P} 44$, these animals were behaviorally tested (see Behavioral testing, below). Some of the animals that were not injected with BrdU were killed on P15 ( $n=4-6$ for each experimental condition), the brain was quickly removed, and the hippocampal region of each hemisphere was dissected and kept at $-80^{\circ} \mathrm{C}$. One hippocampus was used for reverse transcriptase qPCR (RT-qPCR) analysis and the other one for analysis of serotonin levels (see below, High-performance liquid chromatography). The remaining animals ( $n=10-18$ for each experimental condition) were used for behavioral testing in the period from P43 to P44 and killed on P45. The weight of animals was recorded before death. After death, brain was excised and weighed, after removal of the brainstem and cerebellum.

\section{Histological procedures}

P15 animals that had received BrdU were decapitated and the brain was removed, cut along the midline, and fixed by immersion in Glyo-Fixx (Thermo Electron) for $24 \mathrm{~h}$ and then dehydrated through a series of ascending ethanol concentrations. Each hemisphere was embedded in paraffin and the right hemisphere was cut with a microtome in series of 8 - $\mu \mathrm{m}$-thick sections that were attached to poly-lysine-coated slides. P45 animals that had received BrdU on P15 were deeply anesthetized with ether and transcardially perfused with saline, followed by $4 \%$ parafor- maldehyde in $100 \mathrm{~mm}$ phosphate buffer, $\mathrm{pH}$ 7.4. Brains were stored in the fixative for $24 \mathrm{~h}$, cut along the midline, and kept in $20 \%$ sucrose in phosphate buffer for an additional $24 \mathrm{~h}$. Hemispheres were frozen and stored at $-80^{\circ} \mathrm{C}$. The right hemisphere was cut with a freezing microtome in $30-\mu \mathrm{m}$-thick coronal sections that were serially collected in PBS. Sections from the dentate gyrus (DG) and subventricular zone (SVZ) of animals injected with BrdU were used for immunohistochemistry and Nissl staining. The SVZ of this study corresponds to the rostral horn of the lateral ventricle and starts at the rostral pole of the lateral ventricle, stretching for $900-1200 \mu \mathrm{m}$ in the caudal direction. Its rostral and caudal borders correspond approximately to $+1.18 \mathrm{~mm}$ and +0.02 $\mathrm{mm}$ planes, respectively, of the Franklin and Paxinos atlas of the mouse brain (Franklin and Paxinos, 1997). In P15 animals, 180-260 8- $\mu \mathrm{m}$ thick sections were obtained from the DG and 100-140 $8 \mu$ m-thick sections from the SVZ. In P45 animals, $60-7830-\mu \mathrm{m}$-thick sections were obtained from the DG and 36-44 30- $\mu$ m-thick sections from the SVZ.

BrdU immunohistochemistry and double-fluorescence immunohistochemistry. One of 20 sections from the DG ( $n=9-13$ sections) and SVZ ( $n=5-7$ sections) of P15 animals and one of six sections from the DG ( $n=10-13$ sections) of $\mathrm{P} 45$ animals were processed for BrdU immunohistochemistry. BrdU immunohistochemistry was performed on the sections mounted on slides for the brains embedded in paraffin and on free-floating sections for the frozen brains. Sections from paraffinembedded brains were processed as previously described (Contestabile et al., 2007) and incubated overnight at $4^{\circ} \mathrm{C}$ with a primary antibody antiBrdU (mouse monoclonal 1:100; Roche Applied Science). Detection was performed with a HRP-conjugated anti-mouse secondary antibody (dilution 1:200; Jackson Immunoresearch) and DAB kit (Vector Laboratories). Sections were counterstained with hematoxylin. Bright field images were taken with a Leitz Diaplan microscope equipped with a motorized stage and a Coolsnap-Pro digital camera (Media Cybernetics). Freefloating sections were processed as previously described (Contestabile et al., 2007). For double-fluorescence immunostaining, sections were incubated overnight at $4^{\circ} \mathrm{C}$ with a primary antibody, rat monoclonal antiBrdU antibody (AbD Serotec), diluted 1:100 in 0.1\% Triton X-100 in PBS and either mouse monoclonal anti-NeuN (Millipore Bioscience Research Reagents) diluted 1:250 in 0.1\% Triton X-100 and PBS or mouse monoclonal anti-glial fibrillary acidic protein (GFAP) (Sigma-Aldrich) diluted $1: 400$ in $0.1 \%$ Triton X-100 in PBS. Sections were then washed in $0.1 \%$ Triton X-100 in PBS for $40 \mathrm{~min}$ and incubated for $2 \mathrm{~h}$ with a Cy3-conjugated anti-rat IgG (1:100; Jackson Immunoresearch) secondary fluorescent antibody for BrdU immunohistochemistry and FITCconjugated anti-mouse IgG (1:100; Sigma-Aldrich) for NeuN or GFAP immunohistochemistry. Fluorescent images were taken with an Eclipse TE 2000-S microscope (Nikon) equipped with an AxioCam MRm (Zeiss) digital camera or with a Leica TCS confocal microscope (Leica Microsystems).

Ki-67 immunohistochemistry. One of 12 sections from the DG $(n=$ 5-6) and SVZ $(n=3-4)$ of P45 animals was permeabilized with $0.1 \%$ Triton X-100 in PBS for 30 min and then blocked for $1 \mathrm{~h}$ in $1 \%$ BSA in $0.1 \%$ Triton X-100 and PBS. Sections were incubated overnight at $4{ }^{\circ} \mathrm{C}$ with rabbit monoclonal anti-Ki67 antibody (Thermo Scientific), diluted $1: 200$ in $0.1 \%$ Triton X-100 in PBS, washed in $0.1 \%$ Triton X-100 in PBS for $40 \mathrm{~min}$, and incubated for $2 \mathrm{~h}$ with a Cy3-conjugated anti-rabbit IgG (1:200) (Jackson Immunoresearch). Fluorescent images were taken with an Eclipse TE 2000-S microscope.

Cleaved caspase-3 immunohistochemistry. One of 20 sections from the DG $(n=9-13)$ and SVZ $(n=5-7)$ of P15 animals and one of 12 sections from the DG $(n=5-6)$ and SVZ $(n=3-4)$ of P45 animals were processed for cleaved caspase- 3 immunohistochemistry. Deparaffinized sections and free-floating sections were permeabilized with $0.1 \%$ Triton $\mathrm{X}-100$ in PBS for 30 min, blocked for $1 \mathrm{~h}$ in 3\% BSA in $0.1 \%$ Triton X-100 and PBS, incubated overnight at $4^{\circ} \mathrm{C}$ with a primary antibody [rabbit cleaved caspase-3 (Asp 175) antibody (Cell Signaling Technology)], and diluted $1: 200$ in 3\% BSA in $0.1 \%$ Triton X-100 and PBS. Sections were washed in $0.1 \%$ Triton X-100 in PBS for $40 \mathrm{~min}$ and incubated for $2 \mathrm{~h}$ with a secondary antibody, Cy3-conjugated anti-rabbit IgG (1:200; Jackson Immunoresearch) diluted in $0.1 \%$ Triton X-100 in PBS and 3\% BSA, and rinsed in $0.1 \%$ Triton X-100 in PBS for 30 min. Fluorescent images were taken with an Eclipse TE 2000-S microscope. 
Nissl method. One of 20 sections ( $n=9-13$ sections) and one of six sections ( $n=10-13$ sections) from the DG of P15 and P45 animals, respectively, was stained with toluidine blue according to the Nissl method.

\section{Measurements}

Number of BrdU-positive cells. BrdU-positive cells were counted in the DG, SVZ, neocortex, and striatum of P15 and in the DG of P45 animals. For BrdU+ cell counting in the neocortex and striatum, we sampled the same sections used for the SVZ. The total number of BrdU-positive cells was estimated by multiplying the number counted in the series of sampled sections by the inverse of the section sampling fraction (1/20 in P15 animals; $1 / 6$ in $\mathrm{P} 45$ animals).

Number of Ki-67-positive cells. Total number of Ki-67-positive cells in the DG and SVZ was estimated by multiplying the number counted in the series of sampled sections by the inverse of the section sampling fraction $(1 / 12)$.

Analysis of phenotypes. Sections from the DG of P45 animals were analyzed for coexpression of either BrdU/NeuN or BrdU/GFAP. The total number of cells of each phenotype was estimated by multiplying the number counted in the series of sections by the inverse of the section sampling fraction (1/6). The number of cells of undetermined phenotype was calculated by subtracting the number of BrdU/NeuN-positive cells plus the number of BrdU/GFAP-positive cells from the total number of $\mathrm{BrdU}+$ cells. The number of cells of each phenotype was then divided by the total number of BrdU + cells to estimate the percentage of cells that were labeled with NeuN, GFAP, or neither of these markers.

Number of apoptotic cells. The number of apoptotic cells was estimated by multiplying the number of cleaved caspase-3-positive cells counted in the series of sections by the inverse of the section sampling fraction $(1 / 20$ in the DG and SVZ of P15 animals; $1 / 12$ in the DG and SVZ of P45 animals).

Stereology of the DG. In the series of Nissl-stained sections, the volume of the granule cell layer $\left(V_{\text {ref }}\right)$ was estimated (West and Gundersen, 1990) by multiplying the sum of the cross-sectional areas by the spacing, $T$, between sampled sections ( $T=160 \mu \mathrm{m}$ in P15 animals and $180 \mu \mathrm{m}$ in P45 animals). Granule cell numerical density was determined using the optical fractionator. Counting frames with a side length of $30 \mu \mathrm{m}$ and a height of $8 \mu \mathrm{m}$, spaced in a $150 \mu \mathrm{m}$ square grid (fractionator), were systematically used. Granule cell nuclei were counted with a $\times 100$ oil objective (1.4 NA; Leitz). Granule cell nuclei intersecting the uppermost focal plane and intersecting the exclusion lines of the count frame were not counted. The neuron density $\left(N_{\mathrm{V}}\right)$ is given by $N_{\mathrm{V}}=\left(\Sigma Q / \Sigma_{\mathrm{dis}}\right) / V_{\mathrm{dis}}$, where $Q$ is the number of particles counted in the dissectors, dis is the number of dissectors, and $V_{\text {dis }}$ is the volume of the dissector. The total number $(N)$ of granule cells was estimated as the product of $V_{\text {ref }}$ and the numerical density $\left(N_{\mathrm{V}}\right)$, given by $N=N_{\mathrm{V}} \times V_{\text {ref }}$

\section{Cultures of hippocampal neurospheres}

Cells were isolated from the hippocampus of newborn (P1-P2) euploid $(n=3)$ and Ts65Dn $(n=3)$ mice and neurosphere cultures were obtained as previously reported (Weiss et al., 1996). To obtain neurospheres, cells were cultured in suspension in DMEM/F12 (1:1) containing B27 supplements (2\%), FGF-2 (20 ng/ml), EGF (20 ng/ml), heparin $(5 \mu \mathrm{g} / \mathrm{ml}$ ), and antibiotics (penicillin, $100 \mathrm{U} / \mathrm{ml}$; streptomycin, $100 \mu \mathrm{g} / \mathrm{ml}$ ). Primary neurospheres were dissociated at $\mathrm{d} 8-10$ using Accutase (PAA) to derive secondary neurospheres. The subculturing protocol consisted of neurosphere passaging every $7 \mathrm{~d}$ with whole culture media change (with freshly added FGF-2 and EGF). All experiments were done using neurospheres obtained after 3-5 passages from the initially prepared cultures. Cell cultures were kept in a $5 \% \mathrm{CO}_{2}$ humidified atmosphere at $37^{\circ} \mathrm{C}$.

\section{Real-time RT-qPCR}

Total RNA was extracted from the hippocampus and neurosphere cultures of euploid and Ts65Dn mice with TriReagent (Sigma-Aldrich) according to the manufacturer's instructions. cDNA synthesis was achieved with $1.0 \mu \mathrm{g}$ of total RNA using the iScript cDNA synthesis kit (Bio-Rad) according to the manufacturer's instructions. The used primer sequences are as follows: (1) 5-hydroxytryptamine (serotonin) receptor 1A (NM_008308), forward, 5' -
ACAGGGCGGTGGGGACTC-3' , and reverse, 5' -CAAGCAGGCGGGGACATAGG-3'; (2) 5-hydroxytryptamine (serotonin) receptor $2 \mathrm{~A}$ (NM_172812.2), forward, 5'-GCCTACAAGTCTAGTCAGCTCCAG-3', and reverse, 5' -ACATCTCTTCCGAGTGTTGGTTCC-3'; (3) solute carrier family 6 [neurotransmitter transporter serotonin (SERT); NM_010484.2], forward, 5'-GATCCCTGCTCACACTGACATC-3' and reverse, 5' CCATAGAACCAAGACACGACGAC-3'; (4) nerve growth factor (NGF; NM_013609.1), forward, 5'-GACGACTCTTCTCTTCCAG-3', and reverse, 5'-CGTGGCTGTGGTCTTATCTC-3'; (5) brain-derived neurotrophic factor (BDNF; NM_007540.4), forward, 5'-GTGACAGTATTAGCGAGTG-3', and reverse, 5'-GCCTTCCTTCGTGTAACC-3'; (6) glyceraldehyde-3-phosphate dehydrogenase (NM_008084.2), forward, 5' GAACATCATCCCTGCATCCA-3', and reverse, 5' -CCAGTGAGCTTCCCGTTCA-3'. Real-time PCR was performed using a SYBR Premix Ex Taq kit (Takara) according to the manufacturer's instructions in an iQ5 real-time PCR detection system (Bio-Rad). Fluorescence was determined at the last step of every cycle. Real-time PCR assay was done under the following universal conditions: $2 \mathrm{~min}$ at $50^{\circ} \mathrm{C}, 10 \mathrm{~min}$ at $95^{\circ} \mathrm{C}, 50$ cycles of denaturation at $95^{\circ} \mathrm{C}$ for $15 \mathrm{~s}$, and annealing/extension at $60^{\circ} \mathrm{C}$ for $1 \mathrm{~min}$. Relative quantification was performed using the $\Delta \Delta \mathrm{Ct}$ method.

\section{High-performance liquid chromatography}

The left hippocampus was homogenized with ultrasonic cell disruptor in Acapulco buffer solution (methanol-acetonitrile-50 mM phosphate buffer, $\mathrm{pH}$ 2.8, 15:8:77, containing $200 \mathrm{mg} / \mathrm{L}$ SDS). One volume of homogenate was diluted in 3 volume water and $50 \mu$ lof portions of clear supernatants were directly injected into a high performance liquid chromatography (HPLC) system, as previously described (Grossi et al., 1989, 1991). Protein levels in the sampled tissue were evaluated by Lowry method. The measured amounts of 5-HT and hydroxyindoleacetic acid (HIAA) were expressed as $\mathrm{pg} / \mathrm{ng}$ protein.

\section{Behavioral testing}

Contextual fear conditioning was administered on P43, $28 \mathrm{~d}$ after the end of treatment with either fluoxetine or vehicle. The test occurred in $30 \times$ $24 \times 21 \mathrm{~cm}$ operant chambers (Ugo Basile). Each chamber was equipped with a stainless-steel rod floor through which a footshock could be administered, two stimulus lights, one house light, and a solenoid, all controlled by ANY-maze computer software (Stoelting). The chambers were located in a sound-isolated enclosure in the presence of red light. Mice were trained and tested on 2 consecutive days (Comery et al., 2005). Training consisted of placing a subject in a chamber, illuminating stimulus and house lights, and allowing exploration for $2 \mathrm{~min}$. An auditory cue [2 Hz clicking via the solenoid; conditioned stimulus (CS)] was presented for $15 \mathrm{~s}$. The $2 \mathrm{~s}$ footshock [ $1.5 \mathrm{mAmp}$; unconditioned stimulus (US)] was administered for the final $2 \mathrm{~s}$ of the CS. This procedure was repeated, and mice were removed from the chamber $30 \mathrm{~s}$ later. Twenty hours after training, mice were returned to the same chambers in which training occurred (context) and freezing behavior was recorded by the experimenter using time sampling ( $10 \mathrm{~s}$ intervals). Freezing was defined as lack of movement except that required for respiration. At the end of the 5 min context test, mice were returned to their home cage. Approximately $1 \mathrm{~h}$ later, freezing was recorded in a novel environment and in response to the cue. The novel environment consisted of modifications including an opaque Plexiglas divider diagonally bisecting the chamber, a Plexiglas floor, and decreased illumination. Mice were placed in the novel environment, and time sampling was used to score freezing for $3 \mathrm{~min}$. The auditory cue (CS) was then presented for $3 \mathrm{~min}$, and freezing was again scored. All phases of the test were recorded and immobility was detected by using the video tracking and ANY-maze analysis software. Freezing scores for each subject were expressed as a percentage for each portion of the test. Memory for the context (contextual memory) for each subject was obtained by subtracting the freezing percentage in the novel environment from that in the context.

\section{Statistical analysis}

Results are presented as the mean \pm SD of the mean. Data from single animals were the unity of analysis. Statistical testing was performed with ANOVA followed by post hoc comparisons with Duncan's test. A probability level of $p<0.05$ was considered to be statistically significant. 
Table 1. Body and brain weights of the experimental groups

\begin{tabular}{|c|c|c|c|c|c|}
\hline Age & & Mean $\pm S D$ & & Mean \pm SD & $p$ \\
\hline \multicolumn{6}{|l|}{ P15 } \\
\hline \multirow[t]{3}{*}{ Body } & Euploid & $7.99 \pm 1.41$ & Euploid + Fluo & $6.94 \pm 0.98$ & $*$ \\
\hline & Ts65Dn & $6.14 \pm 1.77$ & Ts65Dn + Fluo & $4.90 \pm 1.13$ & n.s. \\
\hline & $p$ & $* *$ & & $* * *$ & \\
\hline \multirow[t]{3}{*}{ Brain } & Euploid & $0.40 \pm 0.02$ & Euploid + Fluo & $0.39 \pm 0.03$ & n.s. \\
\hline & Ts65Dn & $0.39 \pm 0.02$ & Ts65Dn + Fluo & $0.37 \pm 0.05$ & n.s. \\
\hline & $p$ & n.s. & & n.s & \\
\hline \multicolumn{6}{|l|}{ P45 } \\
\hline \multirow[t]{3}{*}{ Body } & Euploid & $17.00 \pm 3.89$ & Euploid + Fluo & $17.59 \pm 3.72$ & n.s. \\
\hline & Ts65Dn & $13.73 \pm 3.72$ & Ts65Dn + Fluo & $13.57 \pm 3.47$ & n.s. \\
\hline & $p$ & $*$ & & $* *$ & \\
\hline \multirow[t]{3}{*}{ Brain } & Euploid & $0.45 \pm 0.05$ & Euploid + Fluo & $0.42 \pm 0.03$ & $*$ \\
\hline & Ts65Dn & $0.39 \pm 0.05$ & Ts65Dn + Fluo & $0.37 \pm 0.03$ & n.s. \\
\hline & $p$ & ** & & *** & \\
\hline
\end{tabular}

Body and brain weight (mean \pm SD) in grams of euploid and Ts65Dn mice that received either fluoxetine (Fluo) or saline in the period P3-P15, measured on P15 and P45. ${ }^{*} p<0.05,{ }^{* *} p<0.01$, ${ }^{* * *} p<0.001$; n.s., not significant (Duncan's test after ANOVA).

\section{Results}

\section{General results}

To establish the general effect of treatment with fluoxetine in the postnatal period P3-P15, we evaluated the body and brain weights on P15 and P45. In agreement with previous evidence (Roper et al., 2006a), at both ages Ts65Dn mice had a lower body weight than euploid mice. A similar difference was present in animals treated with fluoxetine. The comparison of treated versus untreated animals showed no effect of treatment, save for P15 euploid mice, which exhibited a slightly reduced body weight after treatment with fluoxetine. At P15, no brainweight differences were found among groups. At P45, Ts65Dn mice had a smaller brain weight than the euploid counterpart. Treatment with fluoxetine caused a moderate decrease in brain weight in euploid mice but had no effect in Ts65Dn mice (Table 1).

\section{Effect of fluoxetine on proliferation rate}

To establish the short-term effect of fluoxetine on proliferation rate, we injected P15 animals with BrdU and evaluated the number of BrdU + cells in the subgranular zone (SGZ) of the hippocampal DG and SVZ of the lateral ventricle $2 \mathrm{~h}$ after the injection.

Images in Figure $1 A, B$ show patent differences among groups. Quantification of BrdU + cells in the DG indicated that, whereas untreated euploid mice had $\sim 3650$ BrdU+ cells, untreated Ts65Dn mice had only 2150 cells $(-42 \%)$. Treatment with fluoxetine increased the number of BrdU + cells in both groups, so that treated euploid mice had $\sim 5700 \mathrm{BrdU}+$ cells and treated Ts65Dn mice had 4600 cells (Fig. 1C). These figures indicate that treatment had increased cell proliferation by $60 \%$ in euploid and $110 \%$ in Ts65Dn mice. Comparison of treated Ts65Dn with untreated euploid mice showed no differences (Fig. 1C), indicating that fluoxetine had completely restored cell proliferation. In the SZV, untreated euploid mice had $\sim 10,400$ BrdU + cells and untreated Ts65Dn mice had 5500 cells $(-48 \%)$. After treatment with fluoxetine, euploid mice had $\sim 19,500 \mathrm{BrdU}+$ cells and Ts65Dn mice had 15,500 cells (Fig. 1D), indicating an $87 \%$ and an $180 \%$ increase, respectively. A comparison of treated Ts65Dn mice with untreated euploid mice showed that the former had more proliferating cells than the latter (Fig. $1 D$ ), indicating that not only had fluoxetine restored cell proliferation in Ts65Dn mice but that it had rendered it higher than in euploid mice.
Evaluation of the number of cells expressing cleaved caspase-3, a protein that is one of the hallmarks of apoptotic death (Blomgren et al., 2007) in the DG and SVZ, showed that untreated Ts65Dn mice had fewer apoptotic cells than untreated euploid mice in the DG and a similar number in the SVZ (Fig. $1 E, F$ ), suggesting that their reduced number of BrdU+ cells was not due to a greater cell death. The number of apoptotic cells in the DG of both euploid and Ts65Dn mice was not affected by treatment (Fig. 1E), suggesting that the increase in the number of BrdU+ cells was not due to a decreased cell death. In the SVZ, the number of apoptotic cells underwent a moderate decrease in treated versus untreated Ts65Dn mice (Fig. $1 F$ ), suggesting that a reduction in cell death may contribute to the increase in the number of BrdU + cells in treated Ts65Dn mice.

Though the DG and the SVZ are the major neurogenic regions of the postnatal brain, postnatal neurogenesis has been shown to also take place in the striatum (ST) and neocortex (NC) (Luzzati et al., 2007; Cameron and Dayer, 2008). We found that in the ST and NC of Ts65Dn mice there were fewer proliferating cells $(-52 \%$ and $-58 \%$, respectively) than in euploid mice and that treatment with fluoxetine restored cell proliferation (supplemental Fig. 1, available at www.jneurosci.org as supplemental material). All these data show a widespread impairment of neurogenesis in the DS brain and that the positive effect of fluoxetine involves different cell populations.

\section{Effect of fluoxetine on cell survival}

Whereas cells born in the perinatal SVZ migrate to various neocortical areas and to the olfactory bulb (Brazel et al., 2003), the final destination of cells born in the SGZ is the overlying granule cell layer. To establish the long-term effect of fluoxetine on the survival of the newborn cells, we examined the BrdU+ cells present in the DG in animals injected with BrdU on P15 and killed after 1 month. The images in Figure $2 \mathrm{~A}$ show that untreated Ts65Dn mice had fewer BrdU+ cells than untreated euploid mice had and that treated euploid and Ts65Dn mice had a patently larger number of BrdU + cells than the untreated counterpart (Fig. 2A). Quantification of BrdU+ cells showed that untreated Ts65Dn mice had fewer $(-32 \%)$ surviving cells than untreated euploid mice (Fig. $2 B$ ) and that the number of surviving cells was $67 \%$ in treated versus untreated euploid mice and $140 \%$ in treated versus untreated Ts65Dn mice. A comparison of Ts65Dn mice treated with fluoxetine with untreated euploid mice showed that the former had even more (62\%) surviving cells than euploid mice (Fig. 2 B).

The ratio between the number of BrdU+ cells present in the DG 1 month (Fig. $2 B$ ) and $2 \mathrm{~h}$ (Fig. 1C) after a BrdU injection provides an estimate of the net survival rate. We found that the surviving cells were $37 \%$ of the cells labeled on P15 in untreated euploid mice, $43 \%$ in untreated Ts65Dn mice, $40 \%$ in treated euploid mice, and 50\% in treated Ts65Dn mice. These values indicate that though treatment with fluoxetine increased survival rate in both euploid and trisomic mice, this effect was larger in the latter.

In all P45 groups, most of the cells born on P15 had migrated to the granule cell layer and relatively few cells were still in the hilus (Fig. 2C,D). Untreated Ts65Dn mice had a smaller number of BrdU+ cells than euploid mice in the granule cell layer (Fig. $2 C$ ) but not in the hilus (Fig. 2D). After treatment with fluoxetine, Ts65Dn and euploid mice exhibited an increase in the number of surviving cells in both the granule cell layer (Fig. 2C) and hilus (Fig. 2D). In treated Ts65Dn mice, the number of surviving cells became larger than in untreated euploid mice in both layers (Fig. 2C,D). 


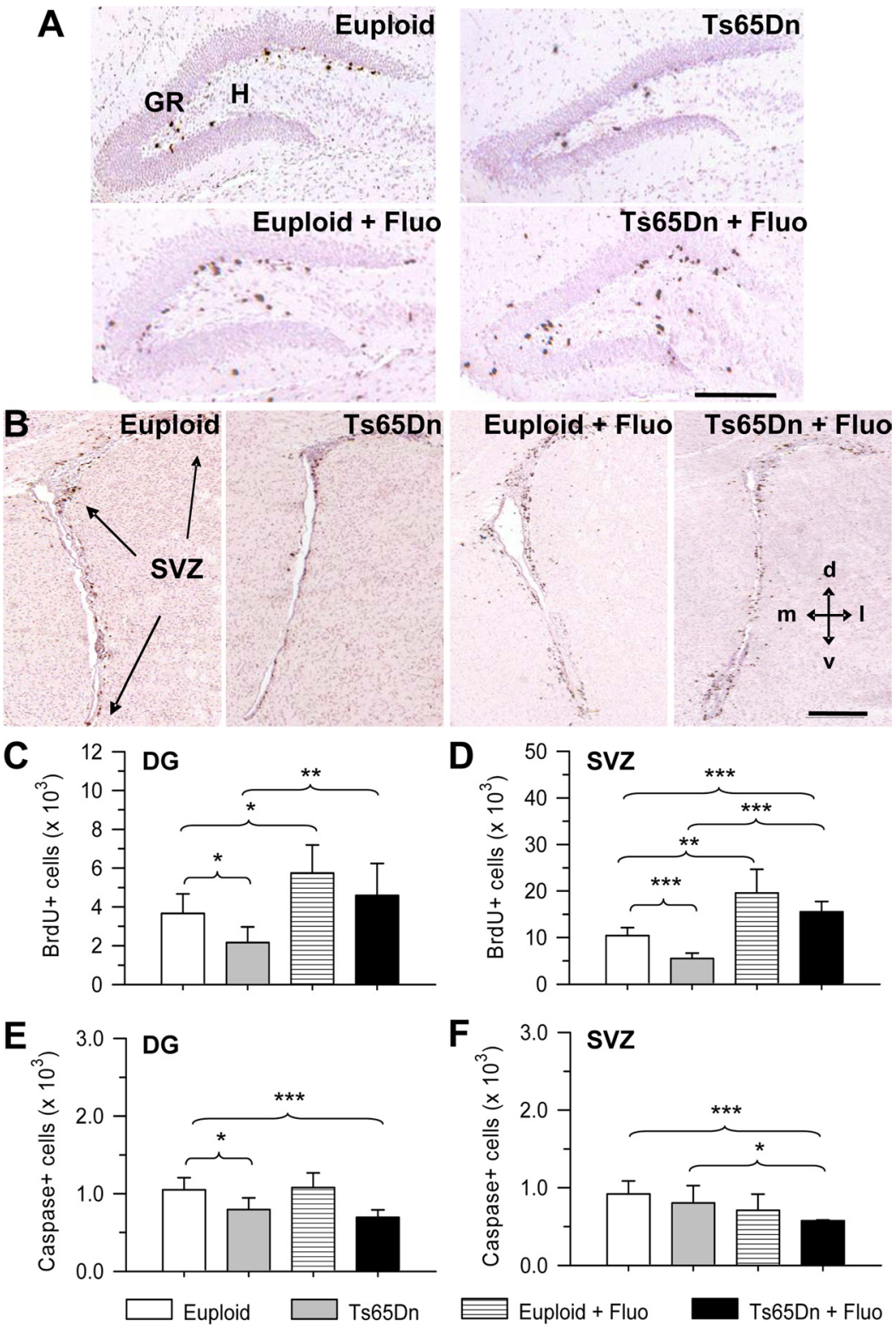

Figure 1. Effect of fluoxetine on cell proliferation in the dentate gyrus and subventricular zone of euploid and Ts65Dn mice. $\boldsymbol{A}, \boldsymbol{B}$, Examples of sections immunostained for BrdU and counterstained with hematoxylin from the $D G(\boldsymbol{A})$ and $\operatorname{SVZ}(\boldsymbol{B})$ of untreated euploid and Ts65Dn mice and euploid and Ts65Dn mice treated with fluoxetine. These animals received one injection of BrdU on P15 and were killed after $2 \mathrm{~h}$. Scale bars $=150 \mu \mathrm{m}$. C, D. Number of BrdU + cells in the DG $(\boldsymbol{C})$ and SVZ (D) of untreated euploid and Ts65Dn mice and euploid and Ts65Dn mice treated with fluoxetine. $\boldsymbol{E}, \boldsymbol{F}$, Number of caspase + cells in the DG (E) and SVZ (F) of untreated euploid and Ts65Dn mice and euploid and Ts65Dn mice treated with fluoxetine. Values in $\boldsymbol{C}-\boldsymbol{F}$ represent totals for one hemisphere (mean \pm SD). ${ }^{*} p<0.05,{ }^{* *} p<0.01,{ }^{* * *} p<0.001$ (Duncan's test after ANOVA). d, Dorsal; Fluo, fluoxetine; GR, granule cell layer; $\mathrm{H}$, hilus; I, lateral; LV, lateral ventricle; $\mathrm{m}$, medial; $\mathrm{v}$, ventral.

Quantification of the number of apoptotic cells in the DG of P45 animals showed that it was smaller than on P15 (Figs. 1E, 2E) and that there were no differences among groups, regardless to either genotype or treatment (Fig. $2 E$ ).

\section{Effect of fluoxetine on the phenotype of the surviving cells}

To establish the effect of treatment on cell fate, we examined the phenotype of the surviving cells in the DG of P45 animals. Untreated Ts65Dn mice had fewer $(-52 \%)$ new neurons (NeuN+/BrdU + cells) (Fig. 3A) and fewer (-37\%) new astrocytes (GFAP+/BrdU+ cells) (Fig. $3 B$ ) than untreated euploid mice. In euploid mice, treatment with fluoxetine increased the absolute number of new neurons (82\%) (Fig. 3A) and new astrocytes (64\%) (Fig. 3B). In Ts65Dn mice, treatment increased the absolute number of new neurons (260\%) (Fig. 3A), new astrocytes (108\%) (Fig. 3B), and cells with an undetermined phenotype (35\%, Fig. 3C) compared with untreated Ts65Dn mice. A comparison of treated Ts65Dn and untreated euploid mice showed that the former had more cells with neuronal (Fig. 3A) and an undetermined (Fig. 3C) phenotype, with no difference in the number of cells with an astrocytic phenotype (Fig. 3B).

A comparison of the phenotype percentage distribution showed that Ts65Dn mice had a reduced percentage of cells with a neuronal phenotype than euploid mice (Fig. 3D) (49\% vs 63\%) and a larger percentage of cells with an undetermined phenotype (Fig. $3 F)$ (27\% vs $13 \%)$. Whereas in euploid mice the phenotype percentage distribution was not affected by treatment with fluoxetine, in Ts65Dn mice there was an increase in the percentage of NeuN+ cells (Fig. 3D) and a decrease in the percentage of cells with an undetermined phenotype (Fig. $3 F$ ). Importantly, the percentage of cells of each phenotype became similar to that found in euploid mice (Fig. 3D-F), indicating that treatment had restored the process of differentiation.

\section{Effects of fluoxetine on the pool of proliferating precursors}

$\mathrm{Ki}-67$ is an endogenous protein expressed by proliferating cells during phases $G_{1}, S$, $\mathrm{G}_{2}$, and $\mathrm{M}$ of the cell cycle (Scholzen and Gerdes, 2000). We used Ki-67 immunohistochemistry to estimate the size of the population of actively dividing cells in the DG and SVZ 1 month after the end of treatment with fluoxetine (on P45). The images in Figure $4 A$ show that in the DG of Ts65Dn mice there were fewer Ki-67+ cells than in euploid mice and that in both groups more Ki-67+ cells were detectable after treatment with fluoxetine. Quantitative analysis showed that untreated euploid mice had $\sim 970 \mathrm{Ki}-67+$ cells and Ts65Dn mice had only 670 cells (-31\%) (Fig. 4B). After treatment with fluoxetine, euploid mice had $\sim 1260 \mathrm{Ki}-67+$ cells (30\%) and Ts65Dn mice had 1540 cells (128\%) (Fig. 4B). A comparison of treated Ts65Dn versus untreated euploid mice showed that the former had significantly more (59\%) Ki-67+ cells (Fig. $4 B$ ). This finding demonstrates that not only had treatment restored the pool of proliferating precursors in Ts65Dn mice but that it had rendered it even larger than that of euploid mice.

Evaluation of Ki-67+ cells in the SVZ showed that untreated euploid mice had $\sim 10,700 \mathrm{Ki}-67+$ cells and Ts65Dn mice had only 7400 cells $(-31 \%)$. After treatment with fluoxetine, euploid mice had $\sim 13,000 \mathrm{Ki}-67+$ cells $(21 \%)$ and Ts65Dn mice had 
9800 cells (32\%). A comparison of treated Ts65Dn versus untreated euploid mice showed that the former had a similar number of Ki-67+ cells (supplemental Fig. $2 B$, available at www.jneurosci.org as supplemental material), demonstrating that treatment had restored the pool of proliferating precursors. Quantification of the number of apoptotic cells in the SVZ of P45 animals showed no differences among groups, regardless of either genotype or treatment (supplemental Fig. 2C, available at www.jneurosci.org as supplemental material).

\section{Effect of fluoxetine on net number of granule cells in the dentate gyrus} We examined the stereology of the DG in P15 and P45 animals to establish the short- and long-term effect of fluoxetine on the net number of granule cells. The granule cell layer had a smaller volume, reduced granule cell density, and reduced number of granule cells in trisomic than euploid mice, both on P15 (Fig. 5A-C) and on $\mathrm{P} 45$ (Fig. 5D-F). The reduction in cell number was $-40 \%$ on $\mathrm{P} 15$ and $-30 \%$ on P45. In euploid mice, treatment with fluoxetine did not change the volume of the granule cell layer (Fig. 5A,D) and though it caused a small but significant increase in granule cell density (Fig. $5 B, E$ ), it did not significantly increase total granule cell number (Fig. 5C,F). In Ts65Dn mice, treatment significantly increased both granule cell density (Fig. $5 B, E$ ) and total granule cell number (Fig. $5 C, F)$. A comparison of treated Ts65Dn and untreated euploid mice showed no stereological differences on either P15 (Fig. 5C) or P45 (Fig. 5F), indicating that fluoxetine had restored development of the granule cell layer.

\section{Effect of fluoxetine on contextual fear conditioning}

To establish the functional consequences of fluoxetine treatment, we evaluated learning function in Ts65Dn and euploid mice using contextual and cued-fear conditioning. Contextual and cuedfear learning are forms of conditioning elicited by pairing a neutral CS (for instance, a sound) with an aversive US (for instance, a footshock) in a distinctive context. When the animal is returned to the context $24 \mathrm{~h}$ later without the conditioned stimulus (old context), it demonstrates a freezing response if it remembers the context. In the cue phase of the test, the animal is placed in a modified environment and when it is exposed to the acoustic conditioned stimulus it generally demonstrates a freezing response if it remembers the cue. Acquisition of the CS-US association is known to require the amygdala (Anagnostaras et al., 1999), whereas acquisition of a context-US association usually requires both the hippocampus and amygdala (Phillips and LeDoux, 1992).

Results of the test performed on P43-P44 are reported in Figure 6 . The values of percentage freezing in the conditioning con- text (old context) and after the conditioning sound (cued cage) in the new environment of the test session ( $\mathrm{d} 2$ ) are reported in Fig. $6, A$ and $B$, respectively. During the test day (P44), untreated Ts56Dn mice showed a significant lower freezing behavior in the old context compared with euploid mice (Fig. 6A), indicating a poorer memory for the context. Treatment with fluoxetine completely restored freezing in Ts65Dn mice and the freezing behavior of fluoxetine-treated Ts56Dn mice in the old context became similar to that of untreated euploid mice (Fig. 6A), indicating that treatment had improved memory for the context. No significant differences were found among groups in freezing behavior after the sound in the new environment (Fig. 6B). These findings suggest that this type of amygdala-dependent response is not grossly impaired in trisomic mice and is not influenced by treatment with fluoxetine.

\section{Effect of fluoxetine on serotonin levels and serotonin receptors}

A profuse network of 5-HT containing axons originating from the dorsal and medial raphe nuclei innervates the hippocampus 


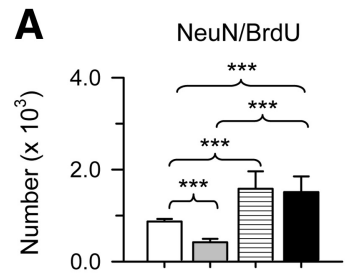

B

GFAP/BrdU
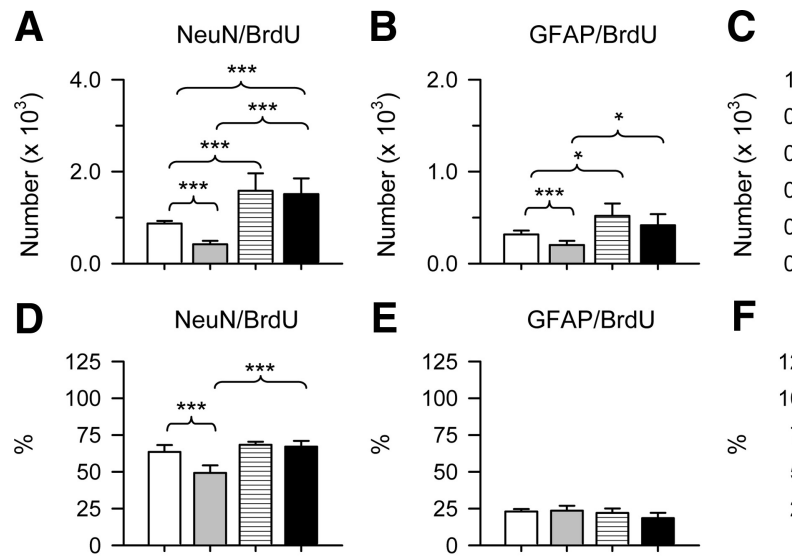

E
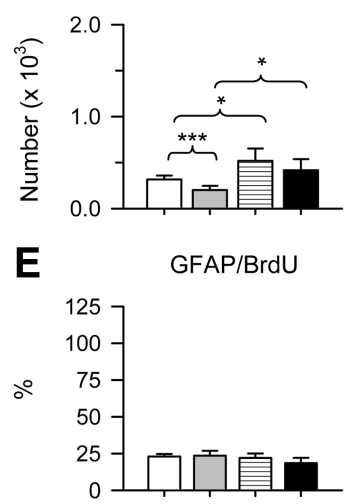

$\mathbf{F}$

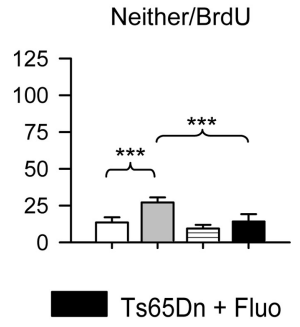

Figure 3. Phenotype of the surviving cells in the dentate gyrus of euploid and Ts65Dn mice. $\boldsymbol{A}-\boldsymbol{F}$, Absolute number $(\boldsymbol{A}-\boldsymbol{C})$ and percentage ( $\boldsymbol{D}-\boldsymbol{F}$ ) of surviving cells with neuronal phenotype (NeuN/BrdU), astrocytic phenotype (GFAP/BrdU), and undetermined phenotype (Neither/BrdU) in the DG (granule cell layer + hilus) of untreated euploid and Ts65Dn mice and euploid and Ts65Dn mice treated with fluoxetine (Fluo). These animals received one BrdU injection on P15 and were killed after 1 month (on P45). Values in $(\boldsymbol{A}-\boldsymbol{C})$ represent totals for one DG (mean $\pm \mathrm{SD}) .{ }^{*} p<0.05,{ }^{* * *} p<0.001$ (Duncan's test after ANOVA).

\section{A}
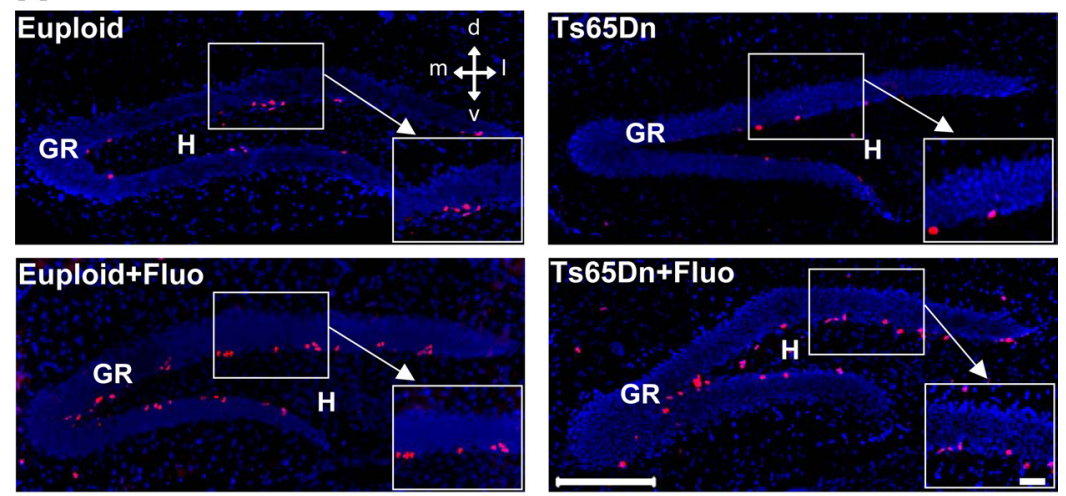

B

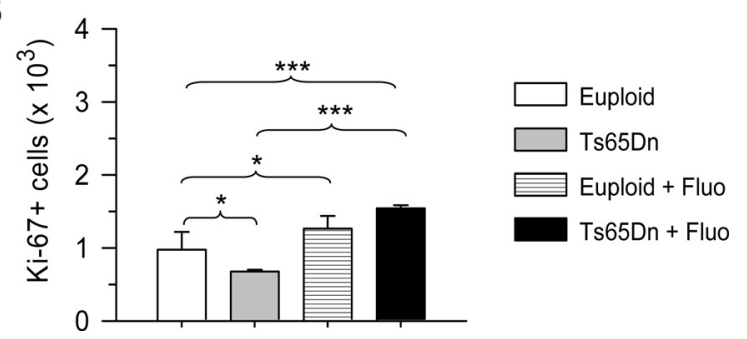

Figure 4. Effect of fluoxetine on the size of the proliferating population in the dentate gyrus of P45 euploid and T565Dn mice. $A$, Examples of sections processed for fluorescent immunostaining for Ki-67 from the DG of untreated euploid and Ts65Dn mice and euploid and Ts65Dn mice treated with fluoxetine, killed on P45. Cells with red nucleus are Ki-67+ cells and cells with blue nucleus are Hoechst-stained granule cells. Scale bars $=200 \mu \mathrm{m}$ (lower magnification) and $40 \mu \mathrm{m}$ (higher magnification). $\boldsymbol{B}$, Total number of Ki-67+ cells in one DG. Values represent mean \pm SD. ${ }^{*} p<0.05,{ }^{* * *} p<0.001$ (Duncan's test after ANOVA). d, Dorsal; Fluo, fluoxetine; GR, granule cell layer; $H$, hilus; I, lateral; $m$, medial; v, ventral.

and DG (Banasr et al., 2004). Quantification of 5-HT by HPLC in the hippocampal region (hippocampus plus DG) of treated and untreated P15 mice showed that Ts65Dn mice had a similar 5-HT concentration as euploid mice (Fig. 7A), a higher concentration of the 5-HT metabolite 5-HIAA (Fig. 7B), and a similar expression of SERT (Fig. 7C) to that of euploid mice. After treatment with fluoxetine, the levels of 5-HT and 5-HIAA underwent a reduction in both euploid $(-40 \%)$ and Ts65Dn $(-45 \%)$ mice
(Fig. $7 A, B$ ). This is in line with evidence showing that, although SSRIs increase extracellular levels of 5-HT (Ceglia et al., 2004), they concomitantly reduce brain levels of 5-HT, due to suppression of 5-HT synthesis (Trouvin et al., 1993; Honig et al., 2009). The expression of SERT was not affected by treatment in Ts65Dn mice and underwent a marginal increase in euploid mice (Fig. 7C).

In view of the role of the $5-\mathrm{HT} 1 \mathrm{~A}$ and 5-HT2A receptors in hippocampal neurogenesis (Banasr et al., 2004), we examined the expression of these receptors in the hippocampal region. Expression of the 5-HT1A (Fig. 7D), but not the 5-HT2A (Fig. 7E) receptor, was smaller in Ts65Dn than in euploid mice. Similar results were obtained in cultures of hippocampal precursor cells (neurospheres) (Fig. 7F,G). After treatment with fluoxetine, Ts65Dn mice exhibited an increase in the expression of the 5-HT1A receptor that became similar to that of untreated euploid mice (Fig. 7D). An increase also took place in treated versus untreated euploid mice, though this difference was only marginally significant. The expression of the serotonin receptor 5-HT2A was not affected by treatment either in euploid or Ts65Dn mice (Fig. 7E).

\section{Effect of fluoxetine on BDNF and NGF expression}

The effects of antidepressants on hippocampal neurogenesis involve two separate processes: the increased proliferation of progenitor cells, which is not regulated by BDNF; and the survival of newborn neurons, which requires BDNF signaling (Sairanen et al., 2005). Reduced BDNF expression has been documented in the frontal cortex of Ts65Dn mice (BimonteNelson et al., 2003). We also found that in the hippocampus of Ts65Dn mice, BDNF expression was lower than in euploid mice (Fig. 8A). Whereas BDNF expression was unaffected by treatment in euploid mice, in Ts65Dn mice it increased and became similar to that of euploid mice (Fig. 8A). Reduced serum levels of NGF have been found in children with DS (Calamandrei et al., 2000). Accordingly, we found a reduced expression of NGF in the hippocampus of Ts65Dn mice. Unlike BDNF, NGF expression was not affected by treatment with fluoxetine (Fig. $8 B$ ).

\section{Discussion}

Our study in a mouse model for Down syndrome provides novel evidence that a widely used antidepressant is able to fully restore neurogenesis during early phases of brain development and that, concomitantly, cognitive behavior is also improved, suggesting that neurogenesis is functionally effective. 
Treatment with fluoxetine restores neurogenesis in Ts65Dn mice

In agreement with previous evidence in fetal, neonate, and adult Ts65Dn mice (Lorenzi and Reeves, 2006; Chakrabarti et al., 2007; Contestabile et al., 2007; Bianchi et al., 2010), young (P15) Ts65Dn mice showed severe proliferation impairment in the SGZ and SVZ. At the end of $13 \mathrm{~d}$ of treatment with fluoxetine during the early postnatal period (P3-P15), cell proliferation notably increased and became similar to (in the SGZ) or even larger than (in the SVZ) untreated euploid mice.

The proliferative effects of fluoxetine in the SGZ and SVZ were not accompanied by a higher death rate and 1 month after cessation of treatment there were still more BrdU+ in the DG of treated mice and more Ki-67+ (cycling) cells in the SGZ and SVZ. This indicates that the short-term effects of fluoxetine on cell proliferation were followed by a positive and enduring effect on cell survival, with an expansion of the pool of cycling cells. The reduced proliferation potency that characterizes the trisomic brain is worsened by reduction in the number of cells differentiating into neurons (Contestabile et al., 2007, 2009; Guidi et al., 2008). Importantly, in Ts65Dn mice not only did fluoxetine increase cell proliferation and survival but it also affected the differentiation program, increasing the percentage of cells that acquired a neuronal phenotype, thereby fully restoring neuronogenesis.

All this evidence indicates that treatment with fluoxetine is able to fully restore neurogenesis in Ts65Dn mice by increasing the number of actively dividing cells, increasing their survival rate, and favoring acquisition of a neuronal phenotype. Neurogenesis in the DG is mainly a postnatal event and in rodents $\sim 80 \%$ of the granule cells are born postnatally, with a peak during the first postnatal week (Schlessinger et al., 1975). Though neurons and glial cells forming the cortical mantle mainly derive from the embryonic ventricular and SVZ, glia and interneurons are still produced by the perinatal SVZ (Brazel et al., 2003). Current findings show that it is possible to rescue the defective proliferation that characterizes the trisomic condition in a time window that is crucial for hippocampal development and important for completion of corticogenesis.

Ts65Dn mice have similar hippocampal 5-HT levels and SERT expression as euploid mice

In Ts65Dn mice, the dorsal and medial raphe nuclei, which give origin to the serotonergic projection to the telencephalon, exhibit a normal pattern (Megías et al., 1997). Consistent with this, we found normal 5-HT levels in the hippocampus of Ts65Dn mice. In addition, similarly to human fetuses with DS (Lubec et al., 2001), Ts65Dn mice had normal SERT expression. Together, these data show no gross abnormalities in the serotonergic input to the hippocampus of Ts65Dn mice, suggesting that 5-HT depletion may not be the determinant of proliferation impairment. However, the fact that brains of adults with DS have lower 5-HT (Risser et al., 1997) and higher SERT levels (Gulesserian et al., 2000) suggests that 5-HT depletion might contribute to the impairment of neurogenesis at advanced life stages.

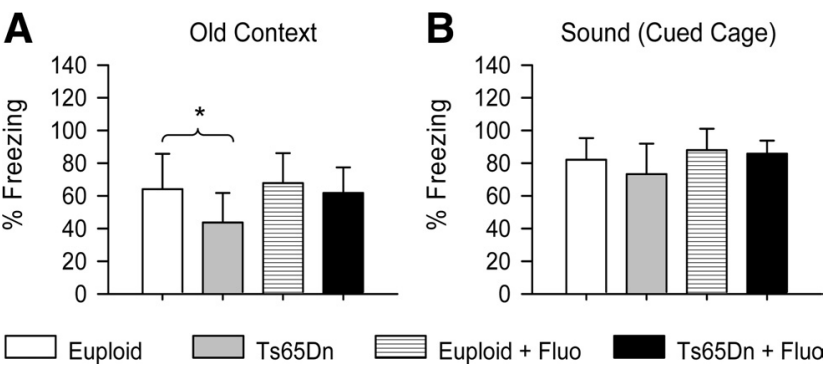

Figure 6. Effect of fluoxetine on contextual fear conditioning. $\boldsymbol{A}, \boldsymbol{B}$, Percentage of freezing in the conditioning context (old context) $(\boldsymbol{A})$ and after the conditioning sound (cued cage) in the new environment of the test session $(\boldsymbol{B})$. See Materials and Methods for explanation. Values are mean $\pm S D$. ${ }^{*} p<0.05$ (Duncan's test after ANOVA).

Fluoxetine-induced neurogenesis increase in the dentate gyrus of Ts65Dn mice is associated with increases in 5-HT1A receptor and $\mathrm{BDNF}$ expression

In the hippocampus, the 5-HT1A receptor plays a key role in the regulation of neurogenesis and the proliferation increase triggered by fluoxetine requires its activation (Malberg et al., 2000; Santarelli et al., 2003; Encinas et al., 2006). We found a reduced expression of the 5-HT1A receptor in the hippocampus of Ts65Dn mice and a similar reduction was present in hippocampal neurospheres, suggesting that defective 5-HT1A receptor expression in precursor cells of Ts65Dn mice may underlie proliferation impairment. This conclusion is supported by the finding that in Ts65Dn mice treatment with fluoxetine restored the expression of the 5-HT1A receptor and that this effect was accompanied by rescue of proliferation. In agreement with previous studies, fluoxetine increased proliferation (Malberg et al., 2000; Clark et al., 2006; Shankaran et al., 2006) and upregulated the expression of the 5-HT1A receptor (Lund et al., 1992) also in the hippocampus of euploid mice, although these effects were smaller than in Ts65Dn mice. In animals with a normal serotonergic system, treatments longer than that used here (13 d) may be required to elicit more overt effects.

BDNF plays a key role in hippocampal neurogenesis by increasing cell survival and neuronal differentiation (Sairanen et 
A

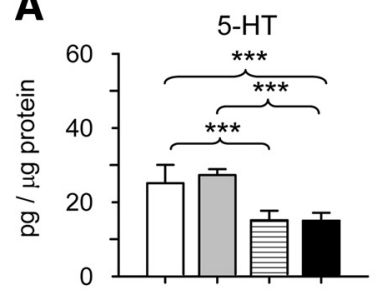

B

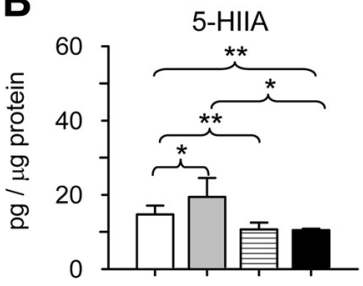

C
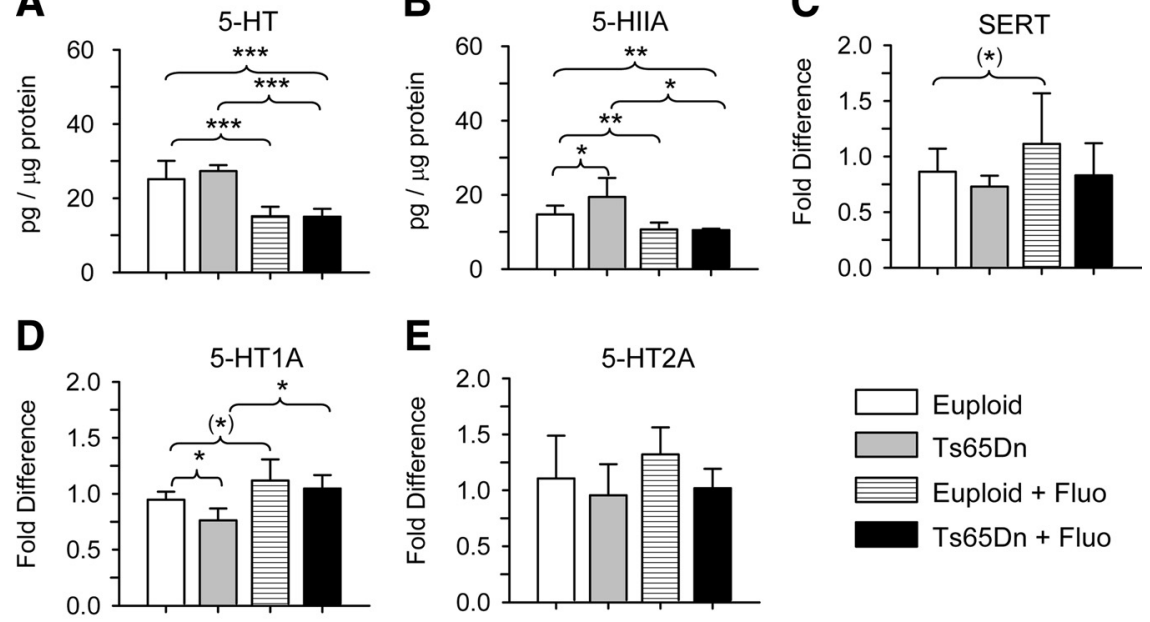

E

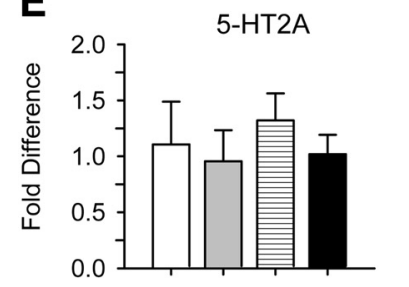

$\mathbf{F}$

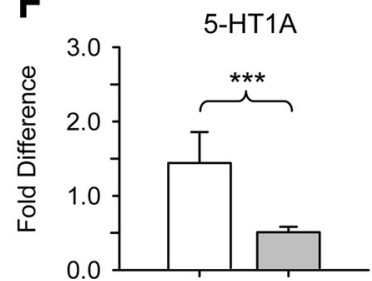

G

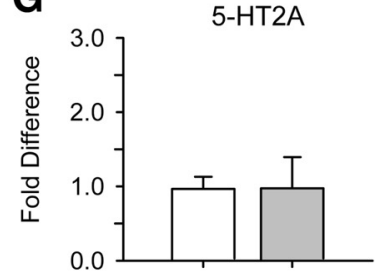

Figure 7. Effect of fluoxetine on serotonin levels and serotonin receptors in the hippocampal formation of euploid and T565Dn mice. $\boldsymbol{A}, \boldsymbol{B}$, Levels of 5-HT $(\boldsymbol{A})$ and of the serotonin metabolite 5-HIAA $(\boldsymbol{B})$, measured with HPLC in the hippocampal formation of P15 untreated euploid and Ts65Dn mice and P15 euploid and Ts65Dn mice treated with fluoxetine (Fluo). Data are mean \pm SD. C $-\boldsymbol{E}$, RNA expression levels of SERT (C), 5-HT1A receptor (D), and 5-HT2A receptor $(\boldsymbol{E})$, quantified by RT-qPCR, in homogenates of the hippocampal formation from P15 untreated euploid and Ts65Dn mice and P15 euploid and Ts65Dn mice treated with fluoxetine. $F, G$, RNA expression levels of the 5-HT1A $(\boldsymbol{F})$ and 5-HT2A $(\boldsymbol{G})$ receptor quantified by RT-qPCR in lysates of cultured hippocampal precursor cells of untreated euploid and Ts65Dn mice. Data (mean \pm SD) in $\mathbf{C}-\mathbf{G}$ are given as the fold difference in comparison with untreated euploid mice. $\left.{ }^{*}\right) p<0.06,{ }^{*} p<0.05,{ }^{* *} p<0.01,{ }^{* * *} p<0.001$ (Duncan's test after ANOVA).

A

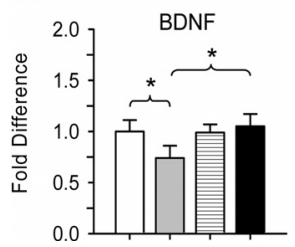

B

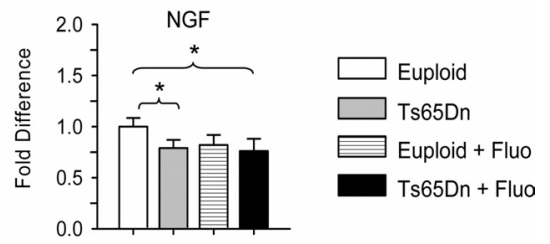

Figure 8. Effect of fluoxetine on neurotrophic factor expression in the hippocampal formation of euploid and Ts65Dn mice. $\boldsymbol{A}, \boldsymbol{B}, \mathrm{RNA}$ expression levels of $\operatorname{BDNF}(\boldsymbol{A})$ and NGF $(\boldsymbol{B})$, quantified by RT-qPCR, in homogenates of the hippocampal formation from P15 untreated euploid and Ts65Dn mice and euploid and Ts65Dn mice treated with fluoxetine (Fluo). Data (mean \pm SD) are given as the fold difference in comparison with untreated euploid mice. ${ }^{*} p<0.05$ (Duncan's test after ANOVA).

al., 2005) and chronic treatment with antidepressants increases its expression (Malberg and Blendy, 2005). In Ts65Dn mice, fluoxetine restored BDNF expression, suggesting that this may be the mechanism whereby treatment increases the survival of newborn cells and restores the differentiation program. Unlike in Ts65Dn mice, in euploid mice BDNF levels were not increased by treatment and the differentiation program was unaffected. Again, it is possible that, in animals with a normal serotonergic system, longer treatments are necessary to upregulate BDNF expression (Malberg and Blendy, 2005). The low NGF levels of Ts65Dn mice were not increased by treatment, suggesting that this neurotrophin is not involved in the treatment-induced improvement of neurogenesis.

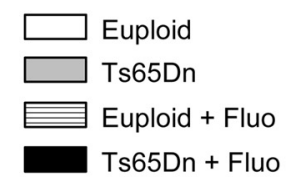

Recent evidence demonstrates that human chromosome 21-derived microRNA are overexpressed in the DS brain and downregulate the expression of the methyl-CpG-binding protein (MeCP2) (Kuhn et al., 2010). Mutations in MeCP2 gene cause the neurodevelopmental disorder Rett syndrome (Amir et al., 1999), suggesting that repression of MeCP2 may contribute to brain abnormalities in DS. Because MeCP2 activates the expression of numerous genes, including 5-HT1A receptor and BDNF (Chahrour et al., 2008), the reduced expression of the latter in Ts65Dn mice may be due to downregulation of $\mathrm{MeCP} 2$. Interestingly, fluoxetine is able to increase MeCP2 expression in the dentate gyrus (Cassel et al., 2006), which might account for the expression increase of the 5-HT1A receptor and BDNF in Ts65Dn mice treated with fluoxetine.

\section{Treatment with fluoxetine restores granule cell number in the dentate gyrus of Ts65Dn mice}

Consistent with their reduced proliferation potency, Ts65Dn mice had fewer granule cells than euploid mice. Granule cell number was restored by fluoxetine, which is in agreement with the positive effect of treatment on neuronogenesis. By as early as P15, treated Ts65Dn mice had acquired a similar number of granule cells as euploid mice and the number remained similar through to $\mathrm{P} 45$. This indicates that a relatively short period of treatment is sufficient to rescue granule cell formation and that this effect outlasts interruption of treatment. Although fluoxetine increased granule cell proliferation, survival, and density in euploid mice, the total granule cell number was unaffected. In euploid mice, the proliferation increase was proportionally smaller than in Ts65Dn mice and, consequently, the relatively low ratio between the newly formed cells and the number of granule cells already present in the granule cell layer may make an increase in total cell number undetectable. This finding is in agreement with evidence for a neurogenesis increase in the DG of enriched animals without an overall effect on granule cell number (Kempermann et al., 1998).

\section{Treatment with fluoxetine improves cognitive function in Ts65Dn mice}

DS is characterized by several behavioral anomalies including hippocampus-dependent memory functions. To test animal behavior, we used contextual fear conditioning, a task that is considered to involve hippocampus-dependent memory functions in addition to the amygdala (Phillips and LeDoux, 1992). In agreement with the impaired development of the dentate gyrus, Ts65Dn mice had a poorer performance in this task than euploid mice. After treatment with fluoxetine, their performance became similar to that of euploid mice, which is consistent with the full recovery of granule cell number. In contrast, no behavioral changes occurred in treated versus untreated euploid mice. The fact that in euploid mice the net number of granule cells was not 
patently increased by fluoxetine (or was increased to a hardly detectable level), may account for the lack of changes in animal behavior.

\section{Conclusions}

No therapies are available at present to improve neurogenesis and mental retardation in individuals with DS. The current study shows that it is possible to increase cell proliferation in numerous regions of the postnatal brain in a mouse model for DS. We have used fluoxetine to stimulate neurogenesis, because it is an antidepressant widely used by adults and prescribed in children and adolescents (Boylan et al., 2007) and it has no patent aversive effects on somatic development (Bairy et al., 2007; Einarson et al., 2009). Treatment during the early postnatal period restored neurogenesis and led to the restoration of the total number of neurons in the dentate gyrus. This effect was accompanied by the full recovery of a cognitive task. The transfer of these data to the human condition would imply that a simple pharmacological treatment during the earliest phases of development might be exploited to improve neurogenesis and, possibly, mental retardation in infants with DS.

\section{References}

Amir RE, Van den Veyver IB, Wan M, Tran CQ, Francke U, Zoghbi HY (1999) Rett syndrome is caused by mutations in X-linked MECP2, encoding methyl-CpG-binding protein 2. Nat Genet 23:185-188.

Anagnostaras SG, Maren S, Sage JR, Goodrich S, Fanselow MS (1999) Scopolamine and Pavlovian fear conditioning in rats: dose-effect analysis. Neuropsychopharmacology 21:731-744.

Bairy KL, Madhyastha S, Ashok KP, Bairy I, Malini S (2007) Developmental and behavioral consequences of prenatal fluoxetine. Pharmacology 79:1-11.

Banasr M, Hery M, Printemps R, Daszuta A (2004) Serotonin-induced increases in adult cell proliferation and neurogenesis are mediated through different and common 5-HT receptor subtypes in the dentate gyrus and the subventricular zone. Neuropsychopharmacology 29:450-460.

Bar-Peled O, Gross-Isseroff R, Ben-Hur H, Hoskins I, Groner Y, Biegon A (1991) Fetal human brain exhibits a prenatal peak in the density of serotonin 5-HT1A receptors. Neurosci Lett 127:173-176.

Bianchi P, Ciani E, Contestabile A, Guidi S, Bartesagh R 2010 Lithium restores neurogenesis in the subventricular zone of the Ts65Dn mouse, a model for Down syndrome. Brain Pathol 20:106-118.

Bimonte-Nelson HA, Hunter CL, Nelson ME, Granholm AC (2003) Frontal cortex BDNF levels correlate with working memory in an animal model of Down syndrome. Behav Brain Res 139:47-57.

Blomgren K, Leist M, Groc L (2007) Pathological apoptosis in the developing brain. Apoptosis 12:993-1010.

Boylan K, Romero S, Birmaher B (2007) Psychopharmacologic treatment of pediatric major depressive disorder. Psychopharmacology (Berl) 191:27-38.

Brazel CY, Romanko MJ, Rothstein RP, Levison SW (2003) Roles of the mammalian subventricular zone in brain development. Prog Neurobiol 69:49-69.

Calamandrei G, Alleva E, Cirulli F, Queyras A, Volterra V, Capirci O, Vicari S, Giannotti A, Turrini P, Aloe L (2000) Serum NGF levels in children and adolescents with either Williams syndrome or Down syndrome. Dev Med Child Neurol 42:746-750.

Cameron HA, Dayer AG (2008) New interneurons in the adult neocortex: small, sparse, but significant? Biol Psychiatry 63:650-655.

Cassel S, Carouge D, Gensburger C, Anglard P, Burgun C, Dietrich JB, Aunis D, Zwiller J (2006) Fluoxetine and cocaine induce the epigenetic factors MeCP2 and MBD1 in adult rat brain. Mol Pharmacol 70:487-492.

Ceglia I, Acconcia S, Fracasso C, Colovic M, Caccia S, Invernizzi RW (2004) Effects of chronic treatment with escitalopram or citalopram on extracellular 5-HT in the prefrontal cortex of rats: role of 5-HT1A receptors. Br J Pharmacol 142:469-478.

Chahrour M, Jung SY, Shaw C, Zhou X, Wong ST, Qin J, Zoghbi HY (2008) $\mathrm{MeCP} 2$, a key contributor to neurological disease, activates and represses transcription. Science 320:1224-1229.

Chakrabarti L, Galdzicki Z, Haydar TF (2007) Defects in embryonic neurogenesis and initial synapse formation in the forebrain of the Ts65Dn mouse model of Down syndrome. J Neurosci 27:11483-11495.
Clark S, Schwalbe J, Stasko MR, Yarowsky PJ, Costa AC (2006) Fluoxetine rescues deficient neurogenesis in hippocampus of the Ts65Dn mouse model for Down syndrome. Exp Neurol 200:256-261.

Comery TA, Martone RL, Aschmies S, Atchison KP, Diamantidis G, Gong X, Zhou H, Kreft AF, Pangalos MN, Sonnenberg-Reines J, Jacobsen JS, Marquis KL (2005) Acute gamma-secretase inhibition improves contextual fear conditioning in the Tg2576 mouse model of Alzheimer's disease. J Neurosci 25:8898-8902.

Contestabile A, Fila T, Ceccarelli C, Bonasoni P, Bonapace L, Santini D, Bartesaghi R, Ciani E (2007) Cell cycle alteration and decreased cell proliferation in the hippocampal dentate gyrus and in the neocortical germinal matrix of fetuses with Down syndrome and in Ts65Dn mice. Hippocampus 17:665-678.

Contestabile A, Fila T, Bartesaghi R, Ciani E (2009) Cell cycle elongation impairs proliferation of cerebellar granule cell precursors in the Ts65Dn mouse, an animal model for Down syndrome. Brain Pathol 19:224-237.

Dierssen M, Vallina IF, Baamonde C, García-Calatayud S, Lumbreras MA, Flórez J (1997) Alterations of central noradrenergic transmission in Ts65Dn mouse, a model for Down syndrome. Brain Res 749:238-244.

Einarson A, Choi J, Einarson TR, Koren G (2009) Incidence of major malformations in infants following antidepressant exposure in pregnancy: results of a large prospective cohort study. Can J Psychiatry 54:242-246.

Encinas JM, Vaahtokari A, Enikolopov G (2006) Fluoxetine targets early progenitor cells in the adult brain. Proc Natl Acad Sci U S A 103:8233-8238.

Fiedler JL, Epstein CJ, Rapoport SI, Caviedes R, Caviedes P (1994) Regional alteration of cholinergic function in central neurons of trisomy 16 mouse fetuses, an animal model of human trisomy 21 (Down syndrome). Brain Res 658:27-32.

Franklin KBJ, Paxinos G (1997) The mouse brain in stereotaxic coordinates. San Diego: Academic.

Granholm AC, Sanders LA, Crnic LS (2000) Loss of cholinergic phenotype in basal forebrain coincides with cognitive decline in a mouse model of Down's syndrome. Exp Neurol 161:647-663.

Grossi G, Bargossi A, Battistoni R, Lippi A, Sprovieri G (1989) Full automation of catecholamine metabolite determination by column switching and high-performance liquid chromatography. J Chromatogr 465:113-119.

Grossi G, Bargossi AM, Lucarelli C, Paradisi R, Sprovieri C, Sprovieri G (1991) Improvements in automated analysis of catecholamine and related metabolites in biological samples by column-switching highperformance liquid chromatography. J Chromatogr 541:273-284.

Guidi S, Bonasoni P, Ceccarelli C, Santini D, Gualtieri F, Ciani E, Bartesaghi R (2008) Neurogenesis impairment and increased cell death reduce total neuron number in the hippocampal region of fetuses with Down syndrome. Brain Pathol 18:180-197.

Gulesserian T, Engidawork E, Cairns N, Lubec G (2000) Increased protein levels of serotonin transporter in frontal cortex of patients with Down syndrome. Neurosci Lett 296:53-57.

Haydar TF, Nowakowski RS, Yarowsky PJ, Krueger BK (2000) Role of founder cell deficit and delayed neuronogenesis in microencephaly of the trisomy 16 mouse. J Neurosci 20:4156-4164.

Honig G, Jongsma ME, van der Hart MC, Tecott LH (2009) Chronic citalopram administration causes a sustained suppression of serotonin synthesis in the mouse forebrain. PLoS One 4:e6797.

Kempermann G, Kuhn HG, Gage FH (1998) Experience-induced neurogenesis in the senescent dentate gyrus. J Neurosci 18:3206-3212.

Kleschevnikov AM, Belichenko PV, Villar AJ, Epstein CJ, Malenka RC, Mobley WC (2004) Hippocampal long-term potentiation suppressed by increased inhibition in the Ts65Dn mouse, a genetic model of Down syndrome. J Neurosci 24:8153-8160.

Kuhn DE, Nuovo GJ, Terry AV Jr, Martin MM, Malana GE, Sansom SE, Pleister AP, Beck WD, Head E, Feldman DS, Elton TS (2010) Chromosome 21-derived microRNAs provide an etiological basis for aberrant protein expression in human Down syndrome brains. J Biol Chem 285:1529-1543.

Liu DP, Schmidt C, Billings T, Davisson MT (2003) Quantitative PCR genotyping assay for the Ts65Dn mouse model of Down syndrome. Biotechniques 35:1170-1174, 1176, 1178 passim.

Lorenzi HA, Reeves RH (2006) Hippocampal hypocellularity in the Ts65Dn mouse originates early in development. Brain Res 1104:153-159.

Lubec B, Yoo BC, Dierssen M, Balic N, Lubec G (2001) Down syndrome 
patients start early prenatal life with normal cholinergic, monoaminergic and serotoninergic innervation. J Neural Transm [Suppl]:303-310.

Lund A, Mjellem-Jolly N, Hole K (1992) Desipramine, administered chronically, influences 5-hydroxytryptamine1A-receptors, as measured by behavioral tests and receptor binding in rats. Neuropharmacology 31:25-32.

Luzzati F, De Marchis S, Fasolo A, Peretto P (2007) Adult neurogenesis and local neuronal progenitors in the striatum. Neurodegener Dis 4:322-327.

Malberg JE, Blendy JA (2005) Antidepressant action: to the nucleus and beyond. Trends Pharmacol Sci 26:631-638.

Malberg JE, Eisch AJ, Nestler EJ, Duman RS (2000) Chronic antidepressant treatment increases neurogenesis in adult rat hippocampus. J Neurosci 20:9104-9110.

Megías M, Verduga R, Dierssen M, Flórez J, Insausti R, Crespo D (1997) Cholinergic, serotonergic and catecholaminergic neurons are not affected in Ts65Dn mice. Neuroreport 8:3475-3478.

Nowakowski RS, Lewin SB, Miller MW (1989) Bromodeoxyuridine immunohistochemical determination of the lengths of the cell cycle and the DNA-synthetic phase for an anatomically defined population. J Neurocytol 18:311-318.

Phillips RG, LeDoux JE (1992) Differential contribution of amygdala and hippocampus to cued and contextual fear conditioning. Behav Neurosci 106:274-285.

Rachidi M, Lopes C (2008) Mental retardation and associated neurological dysfunctions in Down syndrome: a consequence of dysregulation in critical chromosome 21 genes and associated molecular pathways. Eur J Paediatr Neurol 12:168-182.

Reeves RH, Irving NG, Moran TH, Wohn A, Kitt C, Sisodia SS, Schmidt C, Bronson RT, Davisson MT (1995) A mouse model for Down syndrome exhibits learning and behaviour deficits. Nat Genet 11:177-184.

Risser D, Lubec G, Cairns N, Herrera-Marschitz M (1997) Excitatory amino acids and monoamines in parahippocampal gyrus and frontal cortical pole of adults with Down syndrome. Life Sci 60:1231-1237.

Roper RJ, St John HK, Philip J, Lawler A, Reeves RH (2006a) Perinatal loss of Ts65Dn Down syndrome mice. Genetics 172:437-443.

Roper RJ, Baxter LL, Saran NG, Klinedinst DK, Beachy PA, Reeves RH (2006b) Defective cerebellar response to mitogenic Hedgehog signaling in Down's syndrome mice. Proc Natl Acad Sci U S A 103:1452-1456.

Sairanen M, Lucas G, Ernfors P, Castrén M, Castrén E (2005) Brain-derived neurotrophic factor and antidepressant drugs have different but coordinated effects on neuronal turnover, proliferation, and survival in the adult dentate gyrus. J Neurosci 25:1089-1094.

Santarelli L, Saxe M, Gross C, Surget A, Battaglia F, Dulawa S, Weisstaub N, Lee J, Duman R, Arancio O, Belzung C, Hen R (2003) Requirement of hippocampal neurogenesis for the behavioral effects of antidepressants. Science 301:805-809.

Schlessinger AR, Cowan WM, Gottlieb DI (1975) An autoradiographic study of the time of origin and the pattern of granule cell migration in the dentate gyrus of the rat. J Comp Neurol 159:149-175.

Scholzen T, Gerdes J (2000) The Ki-67 protein: from the known and the unknown. J Cell Physiol 182:311-322.

Shankaran M, King C, Lee J, Busch R, Wolff M, Hellerstein MK (2006) Discovery of novel hippocampal neurogenic agents by using an in vivo stable isotope labeling technique. J Pharmacol Exp Ther 319:1172-1181.

Strovel J, Stamberg J, Yarowsky PJ (1999) Interphase FISH for rapid identification of a down syndrome animal model. Cytogenet Cell Genet 86:285-287.

Trouvin JH, Gardier AM, Chanut E, Pages N, Jacquot C (1993) Time course of brain serotonin metabolism after cessation of long-term fluoxetine treatment in the rat. Life Sci 52:PL187-PL192.

Weiss S, Dunne C, Hewson J, Wohl C, Wheatley M, Peterson AC, Reynolds BA (1996) Multipotent CNS stem cells are present in the adult mammalian spinal cord and ventricular neuroaxis. J Neurosci 16:7599-7609.

West MJ, Gundersen HJ (1990) Unbiased stereological estimation of the number of neurons in the human hippocampus. J Comp Neurol 296:1-22.

Whitaker-Azmitia PM (2001) Serotonin and brain development: role in human developmental diseases. Brain Res Bull 56:479-485.

Whittle N, Sartori SB, Dierssen M, Lubec G, Singewald N (2007) Fetal Down syndrome brains exhibit aberrant levels of neurotransmitters critical for normal brain development. Pediatrics 120:e1465-e1471. 